\begin{tabular}{rr} 
çağdaş & Yaratıcı Drama Dergisi 2017, 12(1), 29-46 \\
drama & www.yader.org \\
\hline
\end{tabular}

\title{
Ergenler Yaratıcı Drama Yöntemiyle Hiyerarşi Kavramını Tartışıyor*
}

\author{
Deniz Devrim Şahin ${ }^{1}$ \\ Nejat Akfirat ${ }^{2}$
}

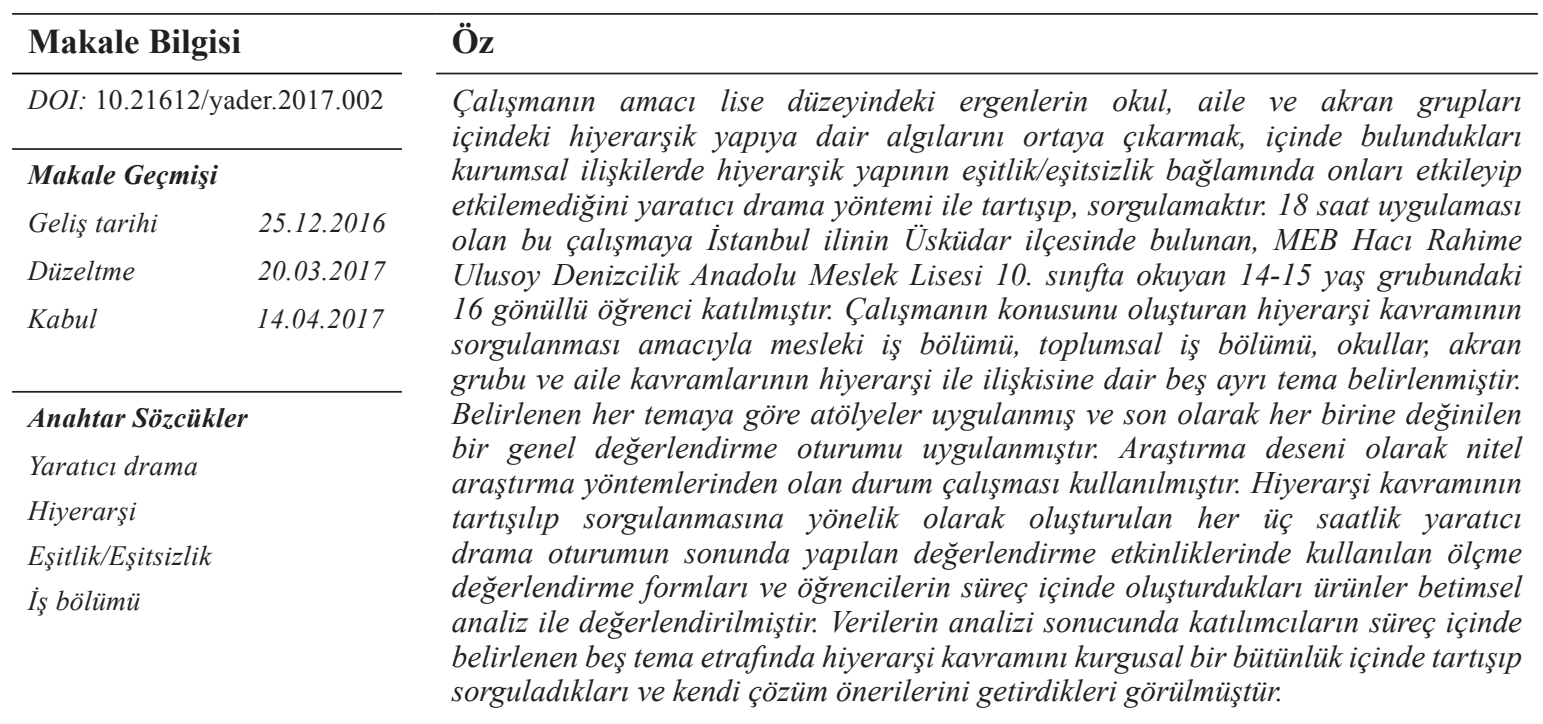

\section{Adolescents Discuss Hierarchy Concept With} Creative Drama Method

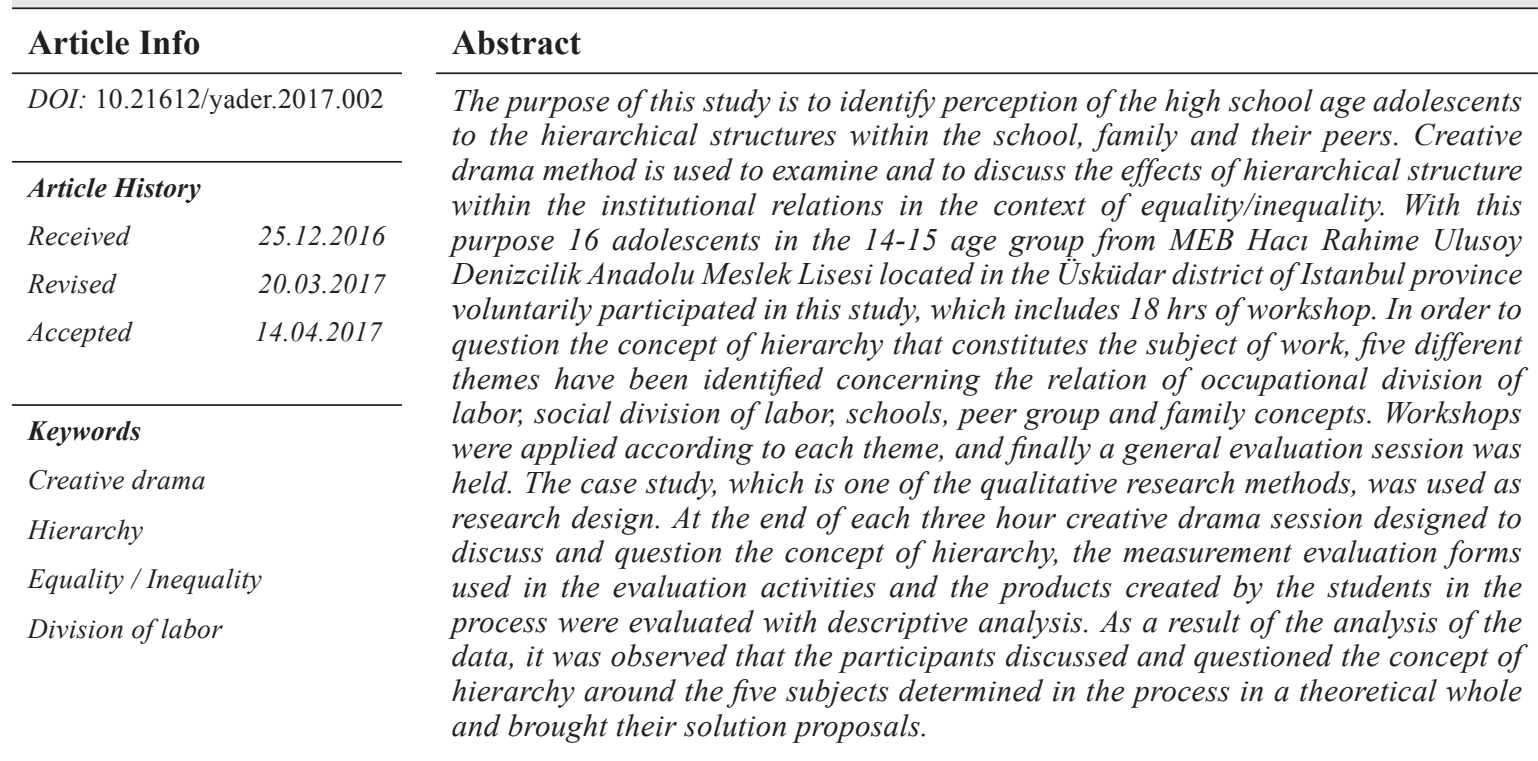

* $\quad$ Bu çalışma MEB Özel Doğaç Yaratıcı Drama Liderliği Projesi’nden geliştirilmiştir.

1 Türk Dili ve Edebiyatı Öğretmeni-Yaratıcı Drama Lideri, E-posta: denizdevrimsahin@gmail.com

2 Yrd. Doç. Dr., Kocaeli Üniversitesi Eğitim Fakültesi Eğitim Bilimleri Bölümü, E-posta: nejatakfirat@gmail.com 


\section{Giriş}

İnsanoğlu topluluklar halinde yaşamaya başladığı günden bugüne değin bir sıralama ve derecelendirme ihtiyacı içinde olmuştur. Bu noktada ortaya çıkan hiyerarşi kavramı hayatın her alanında ve her yaştan kişiyi bir biçimde etkileyen bir kavram olarak karşımıza çıkmaktadır. En genel anlamda "Makam sırası, basamak, derece düzeni, aşama sırası" (TDK, 2013) olarak tanımlanan hiyerarşi genel olarak gündelik algıda bürokrasiyi işaret eden bir kavram olarak görülmektedir. Oysaki bu kavram toplumsal ve kurumsal ilişkilerin pek çok alanında kendisini hissettirmektedir.

Çalışmanın uygulandığ 1 yaş grubunun en çok temas ettiği alanlar olan okul, aile ve akran grubu, lise düzeyindeki ergenlerin toplumsallaştığı, kültürlendiği üç önemli alandır. $\mathrm{Bu}$ çalışma kapsamında, aile ve okul kurumları bireyin "toplumsallaşma" süreci açısından içlerinde barındırdıkları hiyerarşik örgütlenme yapıları yönünden ele alınıp incelenmiştir. Akran grupları ise bu okul ve ailenin kazandırdığı kimliğin denendiği, biçimlendiği ve uygulandığı alan olma özelliği yönünden ele alınmıştır.

Toplumsallaşma, bir toplumun ya da belirli bir grubun normlarını öğrenme ve uyum sağlama süreci olarak ifade edilebilir (Bademci, 2000). Toplumsallaşma süreci bireyin, toplumun kültürüne özümsenmesini sağlar (Fichter, 2002). Toplumların kültürleri tarihsel evrimlerinin ürünüdür. Toplumsallaşma ise onu güçlendirir (K1şlalı,1993). Anlaşıldığı üzere, bireyin öğrendiği yaşama biçimleri, sahip olduğu düşünceler, taşıdığı değerler, bireyin kendi içsel süreçlerinden değil toplumsallaşmasından kaynaklanmaktadır. Sonuçta birey kendi deneyimleri içinden dünyaya bakar ama pencereyi yaratan toplumsallaşma sürecidir (Fichter, 2002).

Giddens'a göre (2000, s.320), “doğumdan ölüme kadar diğer insanlarla etkileşim içinde olmamızın kişiliğimizi ve benimsediğimiz değerleri ve davranış biçimlerimizi etkileyeceği kesindir. Toplumsallaşma süreci boyunca hepimiz bir kimlik duygusu ile bă̆ımsız düşünme ve eylem yeteneği geliştiririz". Kağıtçıbaşı'na (1996) göre de sosyalleşme, “yeterlik” içindir. Çocuk yetiştirme amaca yöneliktir, ancak amaç genellikle belirgin değildir ve bilinçli olarak oluşturulmamış olabilir. Sosyalleşmenin uzun vadede amacı, tanım gereği çocuğu toplumun etkin bir üyesi haline getirmektir.

"Bürokratik ve akademik örgütler oldukça hiyerarşik kıdem ve unvanlara yer veren kuruluşlardır. Bu tip kurumlarda isimden çok rütbe ve unvanlara önem verilir" (Güvenç, 1996, s. 221). Güvenç (1996, s. 221-234), bu durumu açıklarken "bir anlaşmazlık ve çatışma, haksız bir tutum karşısında, 'kim olduğumuzu' sosyal konumlarımızı ve unvanlarımızı kullanarak söz konusu durumdan bu yolla çıkmayı bazı durumlarda ise ayrıcalık beklediğimizi belirtmiş; örnek olarak da 'I. ve II Mevkii Bekleme Salonları', 'VIP Salonları', 'I. Sınıf Lokanta' gibi ayrıcalıklı uygulama örneklerine değinmiştir. Buna göre hiyerarşinin nelere göre ortaya çıtı̆̆ı̆ı şemalaştırmış ve cinsiyet, yaş grupları, rütbe ve kıdem, soyluluk ve saygınlık, kölelik ve esirlik, kast sistemi, kapalı dernekler ve gizli örgütler, soy sop grupları olarak maddelendirmiştir.

İlkel toplumdan günümüz “çağdaş” toplumlarına kadar, insan kendini doğadaki tüm varlıkların en üstüne çekmiş ve doğa ile de hiyerarşik bir ilişki kurmuş ve derecelendirme basamağının en üstüne kendini konumlandırmıştır. Toplumsal farklılaşma ve gruplaşma olarak tanımlanan hiyerarşik alg1 eşitlik/eşitsizlik tartışmasını da beraberinde getirmektedir. Rousseau'nun (akt: Bottomore, 1997) "ahlaki/siyasal eşitsizlik" olarak belirttiği eşitsizlikler "siyasal” kavramında gizlidir, yani eşitsizlik siyasi bir süreçtir ve yine o siyaseti sürdüren neoliberal politikalar ile yaratılıp sürdürülmektedir. 
Turner'ın (1997) Dahrendorf’tan aktardığına göre, doğal ve toplumsal farklılıklar birbirinden ayrıdır. Dahrendorf da Rousseau gibi "doğal ve toplumsal farklılıklar" arasında "değerlendirmeli derecelendirme" getiren eşitsizliklerle getirmeyen eşitsizlikler olarak bir sınıflama yapar ve bu ikisinin birbirinden ayrı düşünülmesi gerektiğini vurgular. Rousseau'nun "doğal farklılıklar" dediği eşitsizlik biçimini “doğal bir derecelenme"den kaynaklı bir eşitsizlik biçimi olarak tanımlar. Bireyler doğal özellikleri ve doğal yetenekleri bakımından farklılaşırlar. Örneğin, kimi uzun kimi kısa boyludur. Bunlar türün "doğal farklılıkları” iken, bazılarının diğerlerinden hızlı koşması ya da uzağ1 daha iyi görmesi doğal “derecelenme farkı”dır. Tuner'a (1997) göre, bu derecelenme fark1 toplumsal bakımdan geçerli olabilir ve toplumsal rol farklılaşmaları, örneğin babalık-annelik gibi, bir toplumsal role atfedilen sıfat ve niteliklere göre belirlenir; ancak bu farklılaşma toplumsal tabaklaşmayı gerektirmez.

Toplumsal yapı içerisinde insanların üstlendikleri rollerin gerektirdiği pek çok davranış kalıbı vardır. Bu davranış kalıplarının biçimlediği roller arasında kurulan ilişki de statü olarak tanımlanmaktadır. Hiyerarşik yapı içerisinde kurulan ilişkiler aynı zamanda bu statülerin kurdukları ilişkiyi de ifade eder. Eğitim kurumlarının ve ailenin bireyi toplumsal yaşantıya hazırlamayı hedefleyen biçimi göz önüne alındığında pek çok kurumsal yapının biçimlendirildiği, hiyerarşik yapının da aktarıldığı ve bireyi bu yaşam formuna hazırlayan yönü açıkça görülecektir. Bu süreçte eğitim yoluyla okul, daha çok "devletin biçimlediğg” kimliği kazandırmaya çalışırken, aile de devletle az ya da çok paralellik taşıyan bir açıdan "toplumsal yapının biçimlediği” kimliği bireye kazandırmaya çalışmaktadır.

$\mathrm{Bu}$ anlamda eğitim sosyolojisi alanında yapılan araştırmalar ışığında eğitime yüklenen farklı rollere kısaca değinmek gerekmektedir. İşlevselci eğitim kuramcıları toplumu dengeli bir sistem olarak ele alırlar. Onlara göre eğitimin birinci işlevi yetenekli kişileri "fırsat eşitliği" ile "seçmek", ikinci işlevi ise bu seçme işlemi ile toplumun gereksindiği "denge"yi kurmasına hizmet etmektir. Marx ve Engels, "Üretici eğitim”i savunmuşlardır. Onlara göre eğitim, üretici iş ile birleştirilmiştir. Böylece, salt kuramsal olan ve ezbere dayalı öğretimin karşıtı bir görüş savunulmuştur. Bedensel iş ile zihinsel iş ayrımı da bu yoldan ortadan kalkmış olacaktır. Althusser'e göre gelişmiş kapitalist sistemlerde temel ideolojik devlet aygıtı eğitimdir. Çünkü eğitim, çocuğu, en uygun olduğu zayıf çağında ve zorunlu olarak ele geçirir ve etkiler. S. Bowles ve H. Gintis, ise öğrencinin okulda, otoriteye uymayı ve güçsüzlüğü kabullenmeyi öğrendiğini söylemektedir. Öğrenciler başarının bireysel liyakatle geleceğini de öğrenirler ki bu da yine "fırsat eşitliği”" algısını canlı tutmak algısına yöneliktir. Onlara göre okul hiyerarşik toplumsal ilişkiler tarafından istila edilen ve otoriteye boyun eğen yapılardır (Tezcan, 1993).

Freire’ye göre ise toplumsal yaşamın amacı, dünyanın insanîleştirilmesidir. Ona göre "insan olmak”, seçimler yapan ve kendi kaderini yönlendirmeye çalışan bir eyleyen olmaktır. "Özgür olmak”, belirleyen olmak, kim olduğunu, çevredeki toplumsal dünya tarafından nasıl biçimlendirildiğini bilmektir. Bu bilinçten yoksun insanlar, tarihin akışı içinde "eyleyen" olamamaktadırlar. Tarihin etkilediği "şeyler" olurlar. Freire bu ezilme durumuna, "Sessizlik Kültürü" demektedir. Öğretmen eylemde bulunur, öğrenciler ise öğretmenin eylemi aracılığı ile eylemde bulunduklarını sanırlar; öğretmen, öğrenme sürecinin öznesi, öğrencilerse nesnesidirler. Bu yöntemin içeriği ve ahlâkî emirleri, yönetici sınıfın ideolojisini yansıtır (Freire, 2011). 
Eğitimle ilgili tüm bu farklı bakış açılarının sayısı artırılabilir. Ancak çalışma konusu göz önüne alındığında eğitim sürecinin hiyerarşik yapısı ve bu yapının bireye yansıması esastır. Eğitimin dünya genelindeki yoksullara, zenginlerin yaşam ve eylemleri üzerinde temellenen bir model olma özelliği (Friere, 2011) Türkiye'de de benzer biçimde gözlenmektedir. "Milli Eğitim” müfredatları incelendiğinde "fırsat eşitliği” ilkesi gereği bireyi "seçkin ortak" yapmak amacı doğrultusunda “...Türk Milletinin milli, ahlaki, insani, manevi ve kültürel değerlerini benimseyen, koruyan ve geliştiren; ailesini, vatanını, milletini seven ve daima yüceltmeye çalışan, insan haklarına ve Anayasanın başlangıcındaki temel ilkelere dayanan demokratik, laik ve sosyal bir hukuk Devleti olan Türkiye Cumhuriyetine karşı görev ve sorumluluklarını bilen ve bunları davranış haline getirmiş yurttaşlar olarak yetiştirmek..." (http://mevzuat.meb.gov.tr/html/88.html) olarak tanımlan Türk Milli Eğitiminin genel amaçlarından alınan bu madde okullarda örtük programların varlığına da işaret ettiği söylenebilir.

Örtük program, “okulda bilinçli ve açık olarak uygulanan programların, kararların, ilkelerin dışında kalan okul ortamı ve yasamı" olarak tanımlamaktadır (Paykoç, 1995, s.53). Vallance (akt: Doğanay ve Sar1, 2004), örtük programı okulun akademik olmayan ancak eğitsel olarak anlamlı çıktıları olarak tanımlamaktadır. Ginsburgh ve Clift (akt: Doğanay ve Sarı, 2004), ise örtük programı daha çok gizli mesajlar anlamında kullanmaktadırlar. Bu noktada hâlihazırda okullarda uygulanan "milli eğitim müfredatı"nın toplumsal yaşama uyum sağlanması ve toplumsal uzlaşmanın devamını sağlayacak örtük hedeflerin yanı sıra hiyerarşik yapının benimsenmesine yönelik örtük hedefleri olduğunu da görmek mümkündür. Günümüz eğitimine hiyerarşik açıdan bakıldığında bilgiyi aktaran olarak bilgi iktidarını da dolaylı olarak elinde bulunduran öğretmene dayalı yöntem ve tekniklerin hâlâ sıklıkla tercih edildiği görülmektedir. Tan, Kayabaşı ve Erdoğan (2003), en çok kullanılan öğretim yöntemlerini sıralarken düz anlatım ve soru cevap yöntemlerini sınırlılıklarını da belirterek zaman, emek ve masraf bakımından ekonomikliği, öğretim konularının belli bir düzene bağlı olarak yapılandırılması, başkalarını dinleme gibi kolaylıkları gibi avantajları nedeniyle en başa koymuşlardır. Tüm bu sayılan avantajlarının yanı sıra anlatanın, soruyu soranın dizgesel bütünlüğü ve bakış açısının yönlendirdiği bir sıralama ve hakim anlayışın da anlatılana aktarılması bu anlatımların hiyerarşi ile yakından ilişkilendirilebileceğini de göstermesi açısından önemli görülmektedir.

Kurumsal yapıları düşünüldüğünde okul ve aile kavramlarının içlerinde barındırdıkları "hiyerarşik yapı" kavramına geniş bir perspektiften bakmak gerekmektedir. Başaran (2013) tarafından, "insanlar, nesneler veya durumlar arasında belirli kriterlere göre gruplama ve kıymet sıralaması yapmak" şeklinde nitelendirilen hiyerarşik yapı "İş yerleri, devlet gibi ortamlarda açıktan, yazılı kurallara göre belirlenen bu kıymet/yetki sıralaması, günlük yaşam içerisinde toplumsal iktidar ilişkilerinin yarattığ 1 kriterlere göre ismi konmadan da işleyebilir.” Okulda daha açık tanımlanabilecek rütbeler ve kıdemler varken ailede bu yapının bu kadar açık olmadığı düşünülebilir. Ancak ataerkil toplumlardaki aile tanımında babadan başlayan hiyerarşik bir rütbe sisteminin, her toplumda farklılık gösterebileceği de göz önünde bulundurulmalıdır. Bu mekanizma hiyerarşik sıra ile baba, anne ve çocuk şeklinde sıralanabilir. Bu anlamda bireyin gelişiminde önemli yer alan aile kavramının yanında, onun bu yapı içerisinden edindiği temel birikimi yaşantıladığı akran grubu da önem arz etmektedir. Ergenlik döneminin temel özellikleri göz önüne alındığında bu dönemde akran grubunun etkisi açıkça görülecektir. Sosyal kabul ihtiyacı ve kendini grup içinde tanımlamak bu dönemin temel eğilimlerindendir. Burada kurdukları ilişki biçimleri asıl olarak onların geçirmiş oldukları eğitim süreci sonucu kendilerine belirledikleri davranış biçimlerini uyguladıkları bir alandır. Hiyerarşik yapıya dair algılarının buradaki yansıması da bu noktada önem kazanmaktadır. 
Eğitimdeki yığmac1, ezberci ve uygucu yaklaşımlar yeni olmayan bir içeriğin öğretildiği ve öğretmenin mutlak otoritesine bağlı, öğrencilerin sürekli boyun eğmesinin beklendiği okul modeli toplumun ihtiyaç duyduğu özgür düşünen, spontan ve yaratıcı bireylerin önündeki en büyük engellerdendir (Adıgüzel, 2012, s. 7). Yaratıcı drama çalışmalarının bu proje açısından en temel özelliği hiyerarşik yapıyı yöntemsel olarak da içermemesidir. Çalışmanın doğası gereği lider, bilgiyi aktaran ve taşıyan değil, ona giden yolda rehberlik edendir. Çember formunda başta ya da sonda olan olmaması, liderin konumunun eğitim alanlardan farklı olmaması bakımından hiyerarşik bir sıralama yoktur. Eşitliği teşvik eder, güven inşa eder. Grup üyelerinin birbirlerinin yanıtlarını doğrudan değerlendirmelerine ve eşit düzlemde tartışmalarına imkân tanır (Yılmaz, 2014). Hiyerarşi kavramının sorgulanıp tartışılmasının hedeflendiği bu çalışmada gerek biçimsel gerek içerik olarak yaratıcı drama yönteminin tercih edilmesinin nedenlerinden biri de yaratıcı dramanın eleştirel düşünmeye, yaratıcılığa ve özgün olana imkan tanıması ve bilgi iktidarının neden olduğu tek ve bir yoldan gidilen bilgiye yer vermemesidir.

\section{Çalışmanın Amacı}

Bu projenin amacı lise düzeyindeki ergenlerin okul, aile ve akran grupları içindeki hiyerarşik yapıya dair algılarını ortaya çıkarmak, içinde bulundukları kurumsal ilişkilerde hiyerarşik yapının onları etkileyip etkilemediğinin yaratıcı drama yöntemi ile tartışıp, sorgulamaktır.

\section{Çalışmanın Uygulandığı Grup}

Bu çalışmaya İstanbul ilinin Üsküdar ilçesinde bulunan, MEB Hacı Rahime Ulusoy Denizcilik Anadolu Meslek Lisesi'nde okuyan 14-15 yaş grubundaki 10. sınıf öğrencileri katılmıştır. Katılımcılar 3’ü kız, 13'ü erkek olmak üzere 16 öğrenciden oluşmaktadır. Öğrencilerin tamamı çalışmaya gönüllü olarak katılmışlardır. Çalışmaya katılan grubun drama yaşantısı bulunmadığı için iletişim ve uyumgüven konulu iki atölye uygulanmıştır. Çalışma konusu olan hiyerarşi kavramının yoğun olarak bulunduğu bir alan olan denizcilik alanında okuyan öğrenciler olmaları grubun seçiminde etken olmuştur. Öğrencilerin konuya yönelik sorgulamaları ve tartışma isteklilikleri de grubun oluşmasını etkilemiştir. Çalışmaya katılan her bir öğrencinin ortaya koyduğu değerlendirmeler analize dahil edilmiştir.

\section{Yöntem}

14-15 yaş grubundan oluşan katılımcıların hiyerarşi kavramına dair algısını yaratıcı drama yöntemiyle araştırmak ve tartışıp, sorgulamak amacıyla yapılan projenin değerlendirilmesinde nitel araştırma yöntemi seçilmiştir. Bu çalışmada nitel araştırma desenlerinden durum çalışması kullanılmıştır. Yin'e (2003) göre, durum çalışması güncel bir olgunun kendi yaşam çerçevesi içinde çalışılması ve birden fazla kanıt veya veri kaynağının mevcut olduğu durumlarda kullanılabilmektedir (akt. Yüksel, 2007). Nitel araştırmada durum araştırma deseni, var olan veya oluşmakta olan bir durumun derinlemesine incelenmesine olanak sağlar (Glense, 2011). Durum çalışmasının araştırmacının "neden?" ve "nasıl?" sorularına odaklanarak "hedeflenen durumu" derinlemesine ve ayrıntılı olarak irdelemesine olanak sağlaması nedeni ile kullanılmıştır. Katılımcıların eğitimini aldıkları meslek grubu nedeniyle hiyerarşik iş bölümü, toplumsal hiyerarşi gibi kavramlarla olgusal boyutun yanı sıra yaşamsal bir ilişki içinde olması bu seçimi belirleyen etmenlerdendir. 


\section{Verilerin toplanması}

Çalışmanın veri toplama kısmında, projede uygulanan yaratıcı drama atölyelerinde yapılan etkinliklerin ara değerlendirme verileri, atölyeler sürecinde oluşturulan çizimler, süreç içinde yazılan mektuplar ve atölye sonlarında kısımlarında uygulanan ölçme-değerlendirme çalışmaları ve formları katılımcıların hiyerarşik yapı ile ilgili görüşlerini değerlendirmek amacıyla veri toplama aracı olarak kullanılmıştır. Bunun yanında genel değerlendirme aşamasında ortaya çıkan veriler ve sürecin bütünü değerlendirme adına oluşturulmuş "Bireysel Süreç Değerlendirme Kitapçı̆̆ı” aracılı̆̆ıyla toplanmıştır. Kitapçık, uygulama sürecindeki kurgusal yapıya uygun olarak hazırlanmış, katılımcıların kurgusal ada yolculuklarını ve yaşantılarını hatırlatması açısından uygulamanın her aşamasına yönelik fotoğraf çıktıları ile birlikte katılımcılara dağıtılmıştır. Bu kitapçık yoluyla katılımcılardan; bütün süreç konusundaki düşünceleri, hiyerarşi kavramına dair algıları ve yaratıcı drama yönteminin işlevselliği ile ilgili yanıtları toplanmıştır. Ayrıca uygulanan bütün atölyeler, öğrencilerin sürecini nitelikli bir şekilde gözlemek amacıyla video kamera ile süreç sonunda değerlendirmek üzere kayıt altına alınmıştır.

\section{Verilerin Analizi}

Verilerin incelenmesi ve çözümlenmesinde betimsel analiz kullanılmıştır. Betimsel analizde veriler daha önceden belirlenen temalar doğrultusunda incelenir ve yorumlanır. Belirlenen temalar doğrultusunda düzenlenmiş ve yorumlamış bulgular neden sonuç ilişkisi ile irdelenerek okuyucuya aktarılır (Yıldırım ve Şimşek, 2011).

Çalışma kapsamında lise düzeyindeki ergenlerin okul, aile ve akran grupları içindeki hiyerarşik yapıya dair algılarını ortaya çıkarmak, içinde bulundukları kurumsal ilişkilerde hiyerarşik yapının onları etkileyip etkilemediğinin yaratıcı drama yöntemi ile tartışılıp, sorgulanmasına esas teşkil eden Mesleki İş Bölümü, Toplumsal İş Bölümü, Okul ve Hiyerarşi, Akran Grubu ve Aile temaları belirlenmiştir. Bu başlıkların içindeki hiyerarşik yapının katılımcılar tarafından nasıl algılandığı ve yaşandığı durum çalışması ile irdelenmiştir. Çalışmanın uygulama kısmının ana başlıklarını da bu temalar oluşturmuştur.

Uygulama sürecinde toplanan yazılı veriler, ürünler ve ölçme değerlendirme formların doküman incelemesi yoluyla betimsel analizi yapılmıştır.

\section{Bulgular ve Yorum}

Katılımcıların yaratıcı drama yöntemiyle tanışmasını ve sürece hazırlanmalarını sağlamak amacıyla hazırlanan ilk iki atölye bu bölümde değerlendirilmeye dâhil edilmemiştir.

Projede konusunu oluşturan hiyerarşi kavramının sorgulanması amacıyla kullanılan beş ayrı tema belirlenmiştir. Belirlenen her temaya göre atölyeler uygulanmış ve bu atölyeler sürecinde elde edilen veriler bu bölümde incelenmiştir. Atölyelerin yapılandırılması bir kurgu etrafında şekillendirilmiştir.

\section{Mesleki İş bölümü ve Hiyerarşi}

Atölyenin kurgusu gereği katılımcılar bir gemi içinde seyahattedirler. Süreç içerisinde öğrenciler tarafından oluşturulan gemi içindeki görev tanımlarından yola çıkılarak kurgulanan, mesleki iş bölümündeki hiyerarşi kavramı sorgulanmıştır. 
Atölye sonunda uygulanan kurgusal bütünlük içinde oluşturulan ve yazılı olarak uygulanan “Gemi Değerlendirme Formu”ndaki sorulara verilen yanıtlar değerlendirilmiştir. Buna göre katılımcıların tamamı gemi içerisinde iş bölümünün gerekli olduğunu ifade etmişlerdir. İş bölümünün ihtiyaçtan kaynaklı olduğunu ve bu ihtiyacın da belli bir düzen içerisinde olması gerektiğini belirtmişlerdir. Bunun için iş bölümü içerisindeki hiyerarşik yapının gerekli olduğu sonucuna ulaşmışlardır. Atölye sürecinde iş bölümünden kaynaklanan hiyerarşik yapının olumlu sonuçlarının yanında olumsuz etkileri de olduğu belirtilmiştir.

“İ̧̧ bölümü gerekliydi. Çünkü gemideki iş karmaşası önlenmiş ve kimin ne görev yaptığı belli olmuş oluyor ve herkes kendi sorumluluğunu bilmişs oluyor.” (K 1)

"Sistemin dayattı̆̆ bir şey ast üst ilişskisi. Çok bağımsız yerlerde bile bu var ilişsilerde bile var.” (K 12)

Katılımcıların çoğu bu atölye sonucunda bu konuyla ilgili ilk kez bu kadar derinlemesine düşündüklerini belirtmişlerdir. Değerlendirme kapsamında çalışmaya katılan tüm öğrencilere tek tek fikirleri sorulduğunda mesleki iş bölümünden kaynaklanan statülerin toplumsal yaşama yansımaması gerektiği konusunda tamamı hemfikir olmuşlardır. Ancak tartışmalar sonucunda bir kısmı iş bölümünden kaynaklı hiyerarşik sistemin yaşamı da belirleyeceğini ve bunun kaçınılmaz olduğunu belirtmişlerdir. $\mathrm{Bu}$ yansımayı engellemek için bunun farkında olmak gerektiği ve bu uygulamadan sonra kendileri kaptan konumuna geldiklerinde altlarında çalışanlarla daha eşit bir ilişki kurmaları gerektiği sonucuna varmışlardır. Bir kısmı ise otorite kavramının hiç olmaması gerektiğini ama sonucunda bunun bir zorunluluk olduğunu söylemişlerdir.

\section{Toplumsal İş bölümü ve Hiyerarşi}

Süreçte, kurgu içerisinde katılımcılar tarafından oluşturulan geminin firtınada sürüklenmesi sonucu çıktıkları adada kurdukları sosyal yaşam içinde yapılan iş bölümündeki hiyerarşi kavramı sorgulanmıştır.

Atölye sürecinde katılımcılar tarafından adada ihtiyaç olabilecek işler: toplayıcılık, temizlik, baraka yapımcılığı, ustalık, su sağlayıcılığ 1 , ilk yardım, avc1lık, toplayıcılık, keşif grubu, işaretçi, aşçlık ve liderlik olarak belirlemiştir. Katılımcılardan gelen cevaplarda belirtilen işler A4 kağıtlarına yazılarak çalışma alanına rastgele bırakılmıştır. Katılımcıların bu işleri incelemeleri ve bir tercih yapmak istediklerinde hangisini istiyorlarsa ona gitmelerine dayalı etkinlik sırasında hiç gidilmeyen kağıtlar alandan kaldırılmıştır. Etkinlik sonunda en çok tercih edilen iş 5 kişi ile liderlik olmuştur. Etkinliğin devamında çıkarılan kağıtlarda yazan işlerin gerekliliği tartışılmış ve tüm kağıtların mesleklerin önem sırasına göre sıralanması istenmiştir. Grup tarafindan yapılan sıralamada diğer meslekler arasında yer değişikliği yapılırken liderlik hep en üst sırada olmuştur. Yalnız bir katılımcı liderliği su ve yemek sağlayıcılığının ardına yerleştirmiş, bir katılımcı da liderliği sıralamanın en alt basamağına yerleştirmiştir. Ancak mesleklerdeki önem sıralamasındaki dikey yapı korunmuştur.

"Genel olarak yüksek dereceli işler seçildi. Bir seferde 5 lider olduk 13 kişi için bu kadar lider gereksiz.”(K1)

"Hiyerarşiye göre seçim yaptık. Temizlikçi olursam önemsenmem lider olursam önemsenirim diye düşündük. ”(K3)

"İslerin siralamasının bile herkese göre farklılık gösterdiği bir ortamda mutlaka lider olmalı ve topluluğun başında olmall.” (K5) 
"Bizim seçmediğimiz işler kesinlikle yapılması gereken hayati önemi olan işlerdi." (K14)

Katılımcılar işler arasında bir sıralamanın mutlaka olacağını bunun da olmasının toplumsal hayatı düzenleyeceğini belirtirlerken hiçbir mesleğin bir diğerinden önemli ya da önemsiz olmaması gerektiği sonucuna da ulaşmışlardır.

Katılımcılara formda yöneltilen iş bölümünde hiyerarşik sıralama gerekip gerekmediğine dair soruya verilen yanıtlar şu şekildedir: "Olmalı çünkü görevleri isteğe bırakırsak kargaşa çıkardı.” (K 2)

“Olmalı çünkü herkesin işi üst taraftakiler tarafindan belirlenmeli.” (K 5)

“Olmalı çünkü bir işi bir kişi yapabilir. Üst olan en iyi işi yapar.” (K 8)

"Hiyerarşi düzeni sağlar. Kimin kime emir verebileceği belli olur.” (K 11)

“Lider yerine ortak kararla hareket edilmeli. Ast-üst ilişkisi şart değil.” (K 14)

Katılımcılardan büyük çoğunluğu toplumsal yaşamdaki iş bölümü içinde hiyerarşi olmalı yanıtını verirken bir kısmı hiyerarşi olsa da eşitlik gözetilmesi gerektiği yönünde yanıt vermişlerdir. Katılımcıların bir kısmı meslekler arasında ihtiyaçtan kaynaklı bir önem sıralamasının doğal olarak olduğunu belirtirken bir kısmı da hiçbir ihtiyacın diğerinden bağımsız olmadığını ve işler arasında bir önem sıralaması yapmanın da mümkün olmadığını belirtmişlerdir.

Katılımcılar atölye sırasındaki canlandırmalarını değerlendirirken toplumsal cinsiyete dair de görüş bildirmişlerdir. Toplumsal cinsiyet rollerinin de iş bölümü üzerindeki etkisi olduğu atölye sürecinde yapılan canlandırmalarda ortaya çıkmıştır. Bu anlamda kadın öğrencilerle yapılan yarı yapılandırılmış görüşmede yer alan ifadeleri şöyledir:

- Adada kız olduğum için bana yemek işleri verildi. Oysa gemide üst düzey işim vard 3. Kaptandım buna ră̆men bana temizlik işini de vermeye kalktılar. Çünkü toplumda kadına yüklenen işler bunlar, ben de fazla itiraz etmeden kabul ettim sorun çıkmasın diye. Aslında en başta adadaki işler ile oynadığımız oyunda ben hep liderlik kartına gitmiştim ama canlandirmalarda hem yemek hem temizlik işi bana düşü̈. Hatta işin ilginci önce yemek yapma işini canlandırmayı kurarken ben aldım ve sonra bir de temizlik işini bana vermelerini söyledim. Bu benim için çok ilginç oldu hiç farkında olmadan bu rolleri alıyoruz bu da bize annelerimiz ve gelenek tarafindan ögretiliyor.

- Ben de canlandırmada sağlık görevlisi rolündeydim. Oysa erkekler de ilk yardım dersi alıyor ama bu tür işleri kadınlar yapar diyorlar ve erkek işi değilmiş gibi davranıyorlar. Bence de bunu ailelerimizden öğreniyoruz. Çünkü bu bizim yaşantımızda da böyle, evin işini, yemeğini annem yapar ve ben de ona yardım ederim. Yani bu işi bize sadece annemiz değil aslında toplum belirliyor. Biz bu işleri aslında kabul ediyoruz.

- Ben canlandırmada çivi çakmaya çalışırken bir erkek arkadaşım gelip, bu erkek işi sen beceremezsin sen git temizlik yap, dedi. Örneğin ben küçüklüğ̈̈mden beri futbol oynartm ve mahallede de okulda da oyun oynamak istediğimde herkes bunu garipsiyor ve oynayamayacağımı düşünüyor, oysa çok iyi oynadığımı görünce de şaşırıyorlar. Benim gibi bir kızın futbol oynaması onlara garip geliyor. Ben bu konuda erkeklerin ve geleneklerin etkisi kadar televizyonların ve dizilerin de etkisi 
olduğunu düşünüyorum. Sonuçta denizcilik de erkek işi diye tanımlanıyor toplumda. Erkek ögrencilerle yapılan yarı yapılandırılmış görüşmede yer alan ifadeleri ise şöyledir:

-Temelde bizim aramızda kimsenin bu ayrımı benimsemediğini, buna dikkat etiğimizi düşünüyorduk. Ama burada böyle çıkması ilginç oldu. Bu konuda daha çok düşünmeliyiz.

- Bu işler kadınların içgüdüsel yaptı̆̆ işlerdir. Oyüzden de toplumsal yaşamda onlar o işleri alıyor. Neticede güçlü değiller. Ben avcılı̆̆ı seçtim mesela çünkü güçlüyüm oysa bir kadın bu işin altından kalkamayabilir. Ama toplumsal yaşamda bu ayrım olmamall.

- Burada kızlar genelde lider olmayı seçti onlar da güç gerektiren işleri seçmediler aslında. Ben bunların geleneklerle ve sisteme dayalı olarak öğrenildiğini düşünüyorum. Oysa kadınlar da artık her işte aletler ve makineler kullanıldiğı için her işi yapabilirler.

- Örneğin ben aşçılığı seçtiğimde de herkes beni garipsedi. Erkek olmama rağmen ben o işi seçtim ama beni de garipsediler.

- Üç kız arkadaşımızda lider kâğıdına gitmişti ama canlandırmalarda kendileri de hiç lider rolünü istemediler bu da ilginç değil mi? Hepsi kendilerine verilen bu işlere çok itiraz etmeden üstlendiler. Bu da onların bunu kabul ettiğini gösterir. Bence de bunlar toplum kadar sistem tarafindan da dayatıllyor. Ve bu çözümlenmeli.

Katılımcıların canlandırmalar esnasında farkında olmadan toplumsal cinsiyete göre davranmaları konusunda tüm kadın öğrenciler bunun gelenek ve toplum yaşantısı içinde içselleştirildiğini belirtirlerken aslında istemeden de olsa bu rolleri benimsediklerini ifade etmişlerdir. Erkek öğrencilerden bir kısmı bunun güce dayalı bir ayrım olduğunu belirtmiş ancak tartışma sonrası gücün de toplumsal yaşamın belirlediği bir tanım olduğu ve mesleklerin cinsiyeti olmayacağ görüşünde birleşmişlerdir.

\section{Okullar ve Hiyerarşi}

Süreç, kurgu içerisinde sürdürülen ada yaşantısı kapsamında öğrencilerin kendi tasarladıkları okullarla mevcut okulları hiyerarşik yapı açısından değerlendirmelerine dayalı olarak yapılandırılmıştır. Katılımcılara kendi deneyimlerini adaya yeni gelecek kişilere aktarabilecekleri ve eğitim alabilecekleri bir yapı kurmaları için yapılan etkinlikte katılımcılar logo ve okul çizimleri yapmışlardır. 

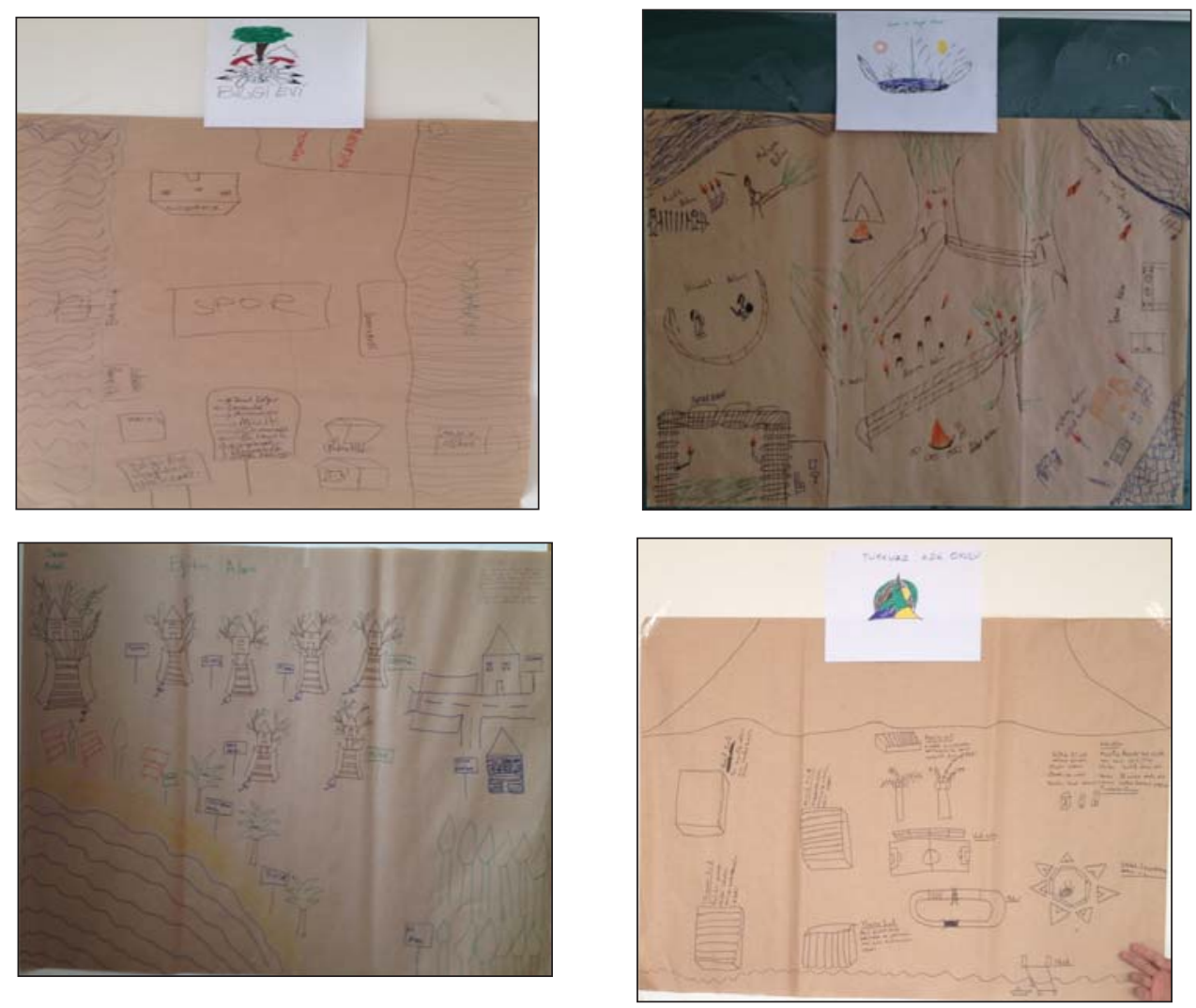

Tüm çizimlerdeki ortak noktalar incelendiğinde katılımcıların kurdukları okullar geniş bir alanda kurulmuş dağınık yapılanmış biçimdedir. Hiçbir okul duvarla ya da çitle çevrili değildir. Okullar mevcut okullardaki sınıf yapılarından farklı olarak uygulama alanlarında eğitim verilmektedir. Mekânlar doğal ortamlar içerisinde uygulama olanağı verecek biçimde tasarlanmıştır. Okulda belirebilecek ihtiyaçların da yine orada ve okulun içerisinde bulunan imkânlarla karşılandığ görülmektedir. Sınıflar dışında tüm okullarda düşünme alanı, sohbet alanı, paylaşım alanı gibi ortak üretim ve fikir paylaşımı alanları oluşturulmuştur. Tüm bunların yanında eğlence ve hobi alanları da ayrıntılı olarak belirlenmiştir. Tasarlanan dört okuldan üçünde "eğitmen”, "lider", "uygulayıcı", "usta öğretici" gibi adlar kullanılırken birinde "katılımcı kolaylaştırıcı" adı tercih edilmiştir. Hiçbir okulda yönetici, müdür gibi görev tanımlarına yer verilmezken temizlik vb. işlerin de o okulda eğitim alacak kişiler tarafından yapılacağı ve ihtiyaçların da okul içinde ayrılan uygulama bölümlerinden sağlanacağı söylenmiştir. Okuldaki teorik dersler için de her okulda büyük bir kütüphane alanı ayrılmıştır. Eğitmenlerin de süreç içinde karşılıklı etkileşim içinde verdikleri eğitimi, öğrenciye göre yeniden yapılandıracakları belirtilirken hiçbir okulda kıyafet vb. mecburiyetlerin olmayacağı vurgulanmıştır. Uygulamalı eğitimin önemini belirten katılımcılar okullarında drama eğitimine de yer vermişlerdir. Tasarlanan okullardan birine özellikle okul adı verilmeyip "Bilgi Evi” adı verdikleri görülmüştür. Katılımcılar bunun nedeninin okul sözcüğünün sistem tarafindan sistemin aktarıldığ1 kurumları temsil etmesi olduğunu belirtmişlerdir.

Atölye çalışmasının ikinci yarısında mevcut okullardan alınan bazı fotoğraflara yer verilmiştir. Fotoğraflarda herhangi bir okulun dışardan çekilmiş bir görüntüsü; öğretmenler odası, sınıf, idareci odalarının herhangi bir tabela içermeyen iç mekân görüntüsü bulunmaktadır. Bu fotoğrafların altına katılımcılardan isim belirtmeksizin yaptıkları yorumlardan bazıları şöyledir: 
Öğretmenler odası ve idareci odaları:

"Bizden değillermiş gibi ayrı bir yerde bulunmaları saçma."

"Geleceğin insanlarını yetiştiren insanların farklı bir odası olması saçma."

"Öğretmen-öğrenci farklı dünyaların insanı."

Okuldan çekilmiş kız, erkek ve öğretmen tuvalet levhaları:

"Hiyerarşi buradan başllyor, öğretmen tuvaletine girilmez."

"Kızlı erkekli tuvalete girebilmek çok doğal bir şey. Hatta az önce girdim."

"Biseksüeller ne yapacak?"

Okul binası ön görüntüsü:

"Köleleşmeden önceki son özgürlük eşiği."

"Nerede ve nasıl sıra olunacağına kadar planlanmış."

"Sistemin evleri."

"En verimli zamanların harcandı $\breve{g}$ yer."

Sıraların mevcut okullardaki arka arkaya dizildiği sınıf fotosu ve tahtada ders anlatan bir öğretmenin bulunduğu sinıf görseli:

"Sıraların arka arkaya olması hiyerarşik."

"Ăgır bir hiyerarşi."

"Bilgi evi diye nitelendirilen bir yerde bu fotoğraf anlamını yitiriyor."

Sözel değerlendirme bölümünde de okulların katlı sistemle yapılmasının bu hiyerarşik yapıyı desteklediği katılımcılar tarafından belirtilmiştir. Sınıf yerleşim planlarının ve makam odalarının da bu yapı içinde en üst katlara yerleştirilmesi, en büyük ve gösterişli odalar olması da hiyerarşik yapının bir göstergesi olduğu belirtilmiştir. Yine kendi okullarındaki sınıflar arası ast-üst ilişkisi ve idari işleyişteki baskı ve kontrol mekanizmaları nedeniyle bu yorumları yaptıkları gözlenmiştir.

"Kat sınıfi temsil eder kat oldukça, sinıflar buna göre yerleşmese de görüntü olarak bu ortaya çıkar. En üstteki alttakine emir verir. Adada ise bir usta çırak ilişkisi var ve katl yapı yok. Gerçek hayattaki gibi kimse birbirine emir vermiyor. Gerçek hayatta hep ezilen en alttaki oluyor. Her gün okula geliyorum yine mi sira yine mi merdiven, yine mi sakal... Beton yığını, hep aynı şeyler. Yaygın bir yapı olsa bir heves olur istediğim yerde vakit geçirip istediğimiz eğitimi alabiliriz.” (K 13)

"Biz aslında çizimlerin hepsinde okulda yaşadığımız sıkıntıları çizdik. Hepimiz uygulamalı eğitim dedik. Sistem kötü.” (K 14)

Okul ve hiyerarşi temasında ön plana çıkan konular okulların katlı yapısı ve hiyerarşi, eğitmen kadrosunun süreci, süreç içinde ve eğitimi alanları merkeze alarak yapılandırması gerekliliği, yönetici kadrosunun eğitsel anlamdaki işlevsizliği ve baskıcı tutumları, uygulamalı eğitim ihtiyacı konularıdır. 


\section{Akran Grubu ve Hiyerarşi}

Süreç, kurgu içerisinde öğrencilerin kendi tasarladıkları okullarda olabilecek ilişkiler içindeki hiyerarşik yapı üzerinden yapılandırılmıştır. Süreç içinde Agusto Boal'den uyarlanan güce dayalı oyunlarda katılımcıların keyif aldıkları gözlemlenmiştir. Özellikle üstünlük elde ederek kendi takımlarına yendikleri kişiyi dâhil ederek gelişen kılıç oyununun devam etmesini istemişlerdir.

Süreç sonunda yapılan sözel değerlendirmede katılımcıların cümleleri:

"Akranlar arasındaki farklılıklar aslında genel olarak güç ve iktidar ilişkisine bağlandl. Birbirimize hangi üstünlüğ̈̈ dayatırsak dayatalım aslında iktidar olmaya çalışıyoruz." (K 4)

"Burada birbirimize üstünlük kurduğumuz şeyler genelde sosyal farklllıklar. Doğal farklılıklar da bu üstünlük çabasında etkili oluyor. Bu farklılıklar biraz da toplum tarafindan dayatılır. Örneğin kızlar yakışıklı, uzun boylu, yapılı erkekleri tercih ediyor, biz ise sarışın mavi gözlü kızları. Bunu bize toplum öğretiyor.” (K 5)

"güçlü olan ister istemez ön plandadır. Bu böyle olmamalı bence ama bunu değiştirmek çok zor ancak burada yaptı̆̆ımız etkinliklerle, yaratıcı dramayla bunu yapabiliriz, yavaş yavaş olur ancak.” (K 7)

Süreç sonu değerlendirmeler katılımcıların doğal ve sosyal farklılıklar üzerinde düşündükleri ve daha çok bu konu etrafında tartıştıkları görülmüştür. Farklılıkların üstünlük sağlama aracı olması konusunda bunun toplumsal algılar tarafından şekillendirildiği görüşü ağırlık kazanırken akran grupları arasında bu tür durumların sıkça yaşandığını da belirtmişlerdir. Katılımcıların süreç başında akran grubu içindeki hiyerarşinin doğal ve değiştirilmesi mümkün olmayan bir hiyerarşi olduğu düşüncesi süreç sonunda kendi algılarındaki değişimin sistemin de değişmesine etki edeceği yönünde değişmiştir.

\section{Aile ve Hiyerarşi}

Süreç kurgu içerisinde öğrencilerin kendi tasarladıkları ailelerde olabilecek ilişkiler içindeki hiyerarşik yapı ve bağ teması üzerinden yapılandırılmıştır. Atölyenin canlandırma bölümünde anne, baba, çocuklar şeklinde gruplanan katılımcılar iplerle kendi grupları içindeki aile bireylerini ve evde onların en çok vakit geçirdikleri mekanlarını oluşturmuşlardır.

Katılımcıların anneye tanımladıkları yaşam alanı mutfak iken babaya tanımladıkları yaşam alanının ise salon olduğu görülmüştür. Çocuklar ise kendi odalarında tanımlanmıştır. Anne, ev kadını, gününü temizlik, yemek ve çamaşır ile geçiren bir kadın olarak tanımlanırken; baba, yoğun çalışma mesaisi olan, evde genellikle salondaki koltukta yatıp televizyonda maç izleyen olarak tanımlanmıştır. Çocukların ise büyük olanın küçük olanın bakımına yardım eden olarak konumlandırıldığı görülürken ailenin sadece akşam yemeği zamanında ortak vakit geçirdiği gözlemlenmiştir. Katılımcıların bu çizimleri günlük yaşam içerisinde gördükleri yapılar üzerinden şekillendirdikleri tartışmalar sonucu ortaya çıkmıştır. Katılımcılar daha önceki toplumsal iş bölümü temalı atölyede yapılan toplumsal cinsiyet tartışmaları üzerinden burada da tekrar paylaşımda bulunmuş toplumsal cinsiyet rollerinin aile içinde de yoğun olarak ortaya çıkıp, üretildiğini belirtmişlerdir.

Çizimdeki ailenin belli durumlar karşısındaki tutumlarının canlandırılmasına dayalı canlandırma bölümünde aile içindeki bireyler hiyerarşik konumları açısından ele alınmıştır. $\mathrm{Bu}$ 
noktada çıkan canlandırmalarda sorunun çözümünde genellikle babanın son noktayı koyduğu, annenin daha çok babanın kararlarını onaylayan ve çocuklara bu kararların doğruluğunu kabul ettirmeye dönük tutum içerisinde olduğu gözlemlenmiştir. Çocuk rollerine bakıldığındaysa büyük çocuğun genellikle hiyerarşik sıralamada küçük çocuk üzerinde baskısı olduğu ve anne-baba tutumlarından en çok etkilenen olarak canlandırıldığı gözlenmiştir.

Genel değerlendirme atölyesinde aile ve hiyerarşi temasına yönelik katılımcı görüşleri:

"Aile içi hiyerarşiyi biz belirliyoruz. Tamamen olmasa da bu konuda değiştirebileceğimiz çok şey var. Bu yüzden kendimizi bu konuda sorgulamalı ve gelişstirmeliyiz.” (K 16)

"Ailede baba TV izleyen, anne yemek yapan, çocuklarsa söz dinleyendir. Ama aslında bizim burada gerçekleştirmek istediğimiz, eksik olduğunu anladı̆̆ımız şey ise eşitlikti. Baba sırf baba olduğu için aile reisi olmamalıyd. Anne sırf kadın olduğu için yemek yapmamallydr. Biz burada bunu fark ettik.” (K 2)

"Ailede baba ve anne kendini kutsal sayıp çocuklara bunlar üzerinde baskı ve duygu sömürüsü yapmamal. O büyük gücü bu şekilde kullanmamalı çocuğunu kaybetmemek için ona baskı yapmamal..” (K 1$)$

"Ailede hiyerarşik düzen olmasın desek de hep olur. Anne ve babanın çocuklar karşısında bir üstünlüğü olur. Hiyerarşi ailede biraz da olmak zorunda.” (K 11)

“Ailedeki hiyerarşik düzen benim için düzenli. Evdeki herkes üstüne düşen görevleri yapmalı. Kendi işini annesinin ya da babasının üstüne bırakmamall. Bir şey yaparken annesinden ve babasından görüş almall, çünkü onlar hayat hakkında daha tecrübeli yaşı gereği ne yapılıp ne yapılmayacă̆ını iyi bildikleri için ailedeki hiyerarşi benim için önemli." (K 15)

\section{Sonuç ve Öneriler}

Bu çalışmada hiyerarşi kavramının yaratıcı drama yöntemiyle sorgulanıp tartışılmasına yönelik oturumlar sonucu elde edilen veriler betimsel analiz yöntemi ile çözümlenmiş ve yorumlanmıştır. Verilerin analizi sonucunda süreç içinde belirlenen kazanımlara ulaşıldığ 1 , daha önceden belirlenen beş tema etrafında hiyerarşi kavramını katılımcıların kurgusal bir bütünlük içinde tartışmalarının sağlandığı görülmüştür. Süreç sonunda konunun yaşam içindeki yeri, katılımcıların mesleki ve toplumsal yaşamdaki hiyerarşi algısındaki düşünsel değişimi-gelişimi katılımcı ifadelerinden ve süreç içindeki gözlemlerden hareketle görülmüştür.

Öğrencilerin kurgusal süreç içerisinde tasarladıkları eğitim kurumlarının taşıdığı fiziksel ve sosyal yapı incelendiğinde; özellikle günümüz eğitim sisteminin uygulamalı ve öğrenci merkezli yapılandırılmasının, eğitim sürecinin öznesi olan birincil ağızdan, ilk koşul olduğunu göstermesi bakımından önemlidir. Buna göre bu çalışmanın farklı eğitim kurumlarında yapılacak uygulamaların program yapılandırmaları sürecinde öğrencilerin bu konuyla ilgili görüşlerinin alınmasında yararlı olacağ1 düşünülmektedir.

$\mathrm{Bu}$ çalışmanın dikey örgütlenme yapısına göre işleyen; dernek, sivil toplum kuruluşları vb. kurumsal kimlikli yapılarda da uygulanması üye ve katılımcıların bu yapıya dair algılarını ve tutumunu göstermesi açısından olumlu sonuç vereceği düşünülmektedir. 
$\mathrm{Bu}$ çalışma, geliştirilerek hiyerarşik yapıdan kaynaklı toplumsal cinsiyet rollerinin mesleki alana ve meslek seçimindeki etkisinin yaratıcı drama yöntemi ile sorgulanmasına yönelik olarak da kullanılabilir. Özellikle toplumsal cinsiyet rollerinin baskın bir biçimde yaşandığı meslek gruplarının mensuplarına, çalışmanın uygulamada bu konuyu tartışma olanağı sağlayacağı düşünülmektedir.

Çalışmanın merkezindeki yaş grubu üzerinde kurgusal bütünlükle uygulama yapmanın süreci dinamik ve etkin kıldığı gözlemlenmiştir. Bu nedenle özellikle toplumsal yaşama dair bir konuyu yaratıcı drama yöntemi ile incelerken kurgusal süreç bütünlüğünün çalışmalara derinlik kazandıracağı düşünülmektedir.

\section{Kaynakça}

Adıgüzel, Ö.H. (2012). Eğitimde yaratıcı drama. (2.Bask1) Ankara: Naturel Yayıncılık

Akfirat, O.N. (2010). Türkiye ve Almanya'da yaşayan üniversiteli Türk gençlerinin siyasal ve toplumsal katılım türlerini ve düzeylerini belirleyen etkenlerin saptanması ve karşılaş̧tırllması. Ankara: A. Ü. Eğitim Bilimleri Enstitüsü Yayımlanmamış Doktora Tezi.

Bademci, V. (2000). Türkiye'deki okullar ne işe yarar?. Ankara: Başkent Yayınevi.

Başaran, Y. (2008). Hiyerarşik olmadan örgütlenmek. Birikim Dergisi, S. 230-231, 67-80.

Bottomore, T.B. (1997). Seçkinler ve toplum. (Çev: Mutlu, E.) 2. Baskı. Ankara: Gündoğan Yayınları.

Demirel, Ö. , Kaya, Z. (2003). Öğretmenlik mesleğine giriş. 4. Baskı. Ankara: Pegema Yayınc1lık

Doğanay, A. ve Sarı, M. (2004). Değerlerin kazandırılmasında açık ve örtük program. Kuram ve Uygulamada Eğitim Yönetimi Dergisi, S.39, Yaz 2004, 356-383.

Fichter, J. (2002). Sosyoloji nedir? (Çev: N. Çelebi). Ankara: Anı Yayıncılık.

Freire, P. (2011). Ezilenlerin pedagojisi. 8. Baskı. İstanbul: Ayrıntı Yayınları

Giddens, A. (2000). Sosyoloji. (Yayına Haz. Özel H., Güzel C.) Ankara: Ayraç Yayınevi

Güvenç, B. (1996). İnsan ve kültür. 6. Bask1. İstanbul: Remzi Kitabevi

http://mevzuat.meb.gov.tr/html/88.html adresinden 25.01.2014 tarihinde alınmıştır.

Kağıtçıbaşı, Ç. (1996). Inssan ve insanlar. 9. Baskı. İstanbul: Evrim Yayınları

Kışlalı, A. T. (1993). Siyaset bilimi. 4.Baskı, Ankara: İmge Kitabevi

Paykoç, F. (1995). Sosyal bilgiler eğitiminde çağdaş eğilimler. İlköğretim okullarında sosyal bilgiler öğretimi ve sorunları. Ankara: TED Yayınları. 46-48.

Şahin, D. D. (2006). OKS Sonuçlarının eğitimsel eşitlik/eşitsizlik bağlamında değerlendirilmesi, , Ankara: Ankara Üniversitesi Sosyal Bilimler Enstitüsü Yayımlanmamış Yüksek Lisans Tezi.

Tan, Ş., Kayabaşı, Y., Erdoğan, A. (2003). Öğretimi planlama ve değerlendirme. 4. Baskı. Ankara: Anı Yayınc1lik.

TDK Sözlüğü. (2013) Ankara: Türk Dil Kurumu Yayınları.

Tezcan, M. (1993) Eğitim sosyolojisinde çă̆daş kuramlar ve Türkiye. Ankara: Ankara Üniversitesi Eğitim Bilimleri Fakültesi Yayınları, No: 170.

Turner, B. (1997). Eşitlik. (Çev: Şener, B. S.) Ankara: Dost Kitabevi.

Yıldırım, A ve Şimşek H. (2011). Sosyal bilimlerde nitel araştırma yöntemleri. Ankara: Seçkin Yayıncılık.

Yılmaz, Ö. (2011). Kapsayıcl, önyargısız eğitim için liderler, öğretmen ve gençlik çalışanları için barış eğitimi rehberi. Ankara: Kayad Yayınları.

Yüksel, S. (2007). Örtük programın öğretmen adaylarının ögretmenlik meslek derslerine yönelik düşüncelerindeki etkisi. Kuram ve Uygulamada Eğitim Yönetimi. S.50, Bahar, 321-345. 


\title{
EK 1: Örnek Oturum Planı (Dördüncü Oturum)
}

\author{
Tarih $\quad: 29.03 .2014$ \\ Konu : Toplumsal Yaşam ve Hiyerarşi \\ Yer : Hacı Rahime Ulusoy Denizcilik Anadolu Meslek Lisesi Üsküdar \\ Grup : : Anadolu Meslek Lisesi 10. sınıf öğrencisi 16 kişi (3 Kadın, 13 Erkek) \\ Süre $\quad: 180$ dakika \\ Yöntem : Yaratıcı drama \\ Teknik : Rol oynama, doğaçlama \\ Araç-Gereç : Pirinç dolu kibrit kutusu, deniz kabukları, kraft kağıdı, renkli kalemler, \\ kraft kağıtları, duvar yapıştırıcısı, renkli bantlar, müzik çalar, şirinler müziği (http://www.youtube. \\ com/watch?v=kTpFQw-y3qY), Ek 3 "Ada Değerlendirme Formu”
}

\section{Kazanımlar :}

Toplumsal yaşamda ortaya çıkan iş bölümü ihtiyacını tartışır.

İş bölümünden kaynaklanan toplumsal rollerin statü ile ilişkisini fark eder.

İş bölümünden kaynaklanan hiyerarşinin gerekliliğini sorgular.

\section{Süreç}

\section{A. Isınma/ Hazırlık Aşaması}

Grup çembere davet edilir. Geçen hafta ile ilgili paylaşmak istedikleri bir şey olup olmadığ sorulur ve bir süre konuşmaları sağlanır. İş bölümü ve ihtiyaç ilişkisi hakkında yeni bir şey düşünüp düşünmedikleri sorulur ve varsa paylaşmaları sağlanır.

1. Etkinlik: Grup üyelerine karışık biçimde dururken her birine kibrit kutuları verilir ve biraz sonra yapacakları etkinlik için kullanacakları ve içinde pirinç olduğu söylenir. Katılımcılara, kutuların aynı anda havaya atılacağı ve kendi attığı kutunun dışında bir kutuyu tutması gerektiği söylenir. Bu sırada hiçbir kutunun yere düşmemesi gerektiği belirtilir. Etkinlikteki düzeni kendilerinin kurmasını sağlamak amacıyla etkinliğe dair detaylı ve doğru yönergeler verilmez. Grubun kendi iş bölümünü oluşturması için sorularla görevi nasıl yerine getirecekleri konusunda tüm grup olarak uzlaşmaları gerektiği söylenir. Bunun için çözüm önerisi olanın “Dur!” diyerek grubu durdurabileceği ve çözüm yolunu önerebileceği belirtilir. Kutuların aynı ikili arasında döndürülmesini engellemek için bu etkinliği grup üyelerinin tamamının birlikte yapması gerektiği hatırlatılır. İşin sağlıklı bir biçimde yapılmasını sağlamak için deneme yapmanın da önemine dikkat çekilebilir (Ali Kırkar'ın 2012 Bahar Dönemi 2. Atölye, Anahtar etkinliğinden uyarlanmıştır.).

Ara Değerlendirme: "Hareketin yapılması neden zor? Grupça kutuların yere düşürülmesini engellemek için ne yapmak gerektir? Kimin hangi kutuyu tutacağının önceden belirlenmesi gerekir mi? Grup içinde tek başına inisiyatif almak ya da liderlik grubu olumlu mu, olumsuz mu etkiler?" sorularla grubun bu konuda çözümler üretmesi sağlanır. Doğru yönergelere ulaşılana ve hareketin doğru iş bölümü ile yapılması için etkinlik belli bir süre devam eder eğer çözüme ulaşılamazsa etkinliğin esas uygulama biçimi anlatılır. 
(Grubun kendi çözümü içinde de bulunabilecek doğru uygulama biçimi: Grup çemberde buluşur. Herkes kutuları sağ elinde tutar. Herkesin kutuyu ayn anda havaya atıp kendi sağına doğru birer adım kayması ve sağındaki kişinin attığı kutuyu yakalaması söylenir. Kibrit kutularının ve adım seslerinin ritminden yararlanılarak grubun ortak bir ritim bularak hareket etmesinin işleyişi kolaylaştıracă̆ı belirtilir.)

2. Etkinlik (Filika Etkinliği): Katılımcılar çembere çağrılır ve grup ikiye ayrılır. Gruplar etkinliklerini sırayla yapacakları, grupların kendi içlerinde arka arkaya dizileceği belirtilir. Elektrik akımı oyunundaki gibi el ele tutuşabilecekleri, bunun birbirlerini hissetmelerini kolaylaştıracağı söylenir. Lider, "Sizler her biriniz denizcisiniz ve bastığınız zemin de sizin içinde bulunduğunuz filika. Hava biraz bozuk ve sert bir rüzgâr var, bu filikanın yol alabilmesi ve dengede kalabilmesi size bağlı. Her biriniz bacaklarınızı birer kürek olarak düşünün, hepinizin aynı anda aynı yöndeki kürekleri çekmesi denge açısından çok önemli. Sizlerin de çok iyi bildiği gibi denizde rotayı kaybetmemek için ufka bakmak hayati bir önem taşır, sizler de kesinlikle birbirinizin ayağına bakmadan yalnızca ufka bakarak bu uyumu yakalamaya çalışacaksınız. Bu esnada konuşmamanız da gruba yoğunlaşmanız açısından önemli. Hareketlerinizi beraber yapmaya odaklanmalısınız. Ufka bakıp bacaklarınızı yanlara doğru kürek gibi aynı anda açıp aynı anda yere basmalı ve aynı anda öbür ayağınızı kaldırmalısınız. Denge bozulduğu an filika batar.” der. Diğer grubun onların seyri esnasında onları izleyeceğini, ayaklarını farklı zamanlarda kaldırdıklarında "gemi battı" diyecekleri söylenir. Filikayı kurtarmak için yalnız 10 hakları olduğu belirtilir. 10 batıştan sonra diğer grup deneyimler (Agusto Boal'den uyarlanmıştır).

\section{B. Canlandırma}

3. Etkinlik: Gruba bir önceki atölyede hazırladıkları rol tanıtım kartlarını tekrar yakalarına takmaları söylenir. 10dan 5'e kadar geriye sayarak her sınma hareketi önce beş kere yaptırılır. Her hareket serisinde 10, 9, 8, 7, 6, 5 sayılır. Hareketlerin yapılış şekli ve sırası şu şekilde olmalıdır: Sağ ayak yerden kaldırılıp sallanır aynısı sol ayak; sağ bacak dizden kıvrılarak karna doğru çekilir, aynısı sol; kalça öne arkaya hareket ettirilir; göğüs bölgesi hareketli diğer taraflar sabit sağa sola hareket ettirilir; omuzlar öne doğru bir seri, arkaya doğru bir seri hareket ettirilir; kollar aşağıdan yukarıya doğru hareket ettirilir; en son vücudun bel hizasından aşağı kıvrılarak nefes bırakıp salınması.

Sonra 10'dan altiya kadar geriye sayarak 4, sonra 10'dan 7'ye, 10'dan 8'e, 10'dan 9'a ve en son 10 ' da tek hareket yaptırılır.

Son harekette 10 dediğinde herkesin kendini yere bırakacağ 1 ve gözlerini yönerge gelene kadar kapalı tutacağı söylenir. Bu sırada lider: "Yolculuğunuzun ikinci gününde gemidekileri limana bıraktınız ve aradan geçen süre içinde gemideki her şeyi gerektiği gibi yürüttünüz. Ama bu mevsimde pek sık rastlanmasa da sıcak rüzgârların neden olduğu hava geçişinden kaynaklı bir firtınaya denk geldiniz. Geminiz sürüklenmeye başladı ve geminin motorları sıcağın da etkisiyle çalışamayacak duruma geldi. Kaptan hepinizi güvertede topladı ve o an hazırda tuttuğu filikayı gösterip, sizler burada çok güzel işler başardınız, ancak artık burada yapılacak bir şey kalmadı ben yardım çağırdım şimdi bu filikaya binmeli ve yardım gelene kadar sabırla beklemelisiniz, erzaklarınızı ve suyunuzu özenli kullanın, dedi. Sizi filikaya bindirdi, sizler kürekleri çekmekte ve filikayı dengede tutmakta zorlandınız ve bir şekilde sürüklenmeye başladınız. Aradan ne kadar geçtiğini anlayamadı̆̆ınız bir süre sonunda içinizden biri kara göründü diye bağırdı ve kalan son gücünüzle filikayı o tarafa doğru yüzdürdünüz. Karaya çıktığınızda hepiniz çok mutluydunuz ama kısa bir süre sonra buranın 1ssız bir 
ada olduğunu anladınız. Çevrede keşif yaptınız ve yaşamak için her imkânın bulunduğunu gördünüz, yaz mevsiminde olduğunuz için ısınma ile ilgili de bir sorununuz yok. Tüm bu koşullar içinde yardım gelene kadar burada kalmaya karar verdiniz. Ve on gündür adadasınız...." der ve katılımcılara hazır olduklarında gözlerini açabileceklerini söyler.

Adada 10 gün geçirdiniz ve artık adayı tanıyorsunuz. Şimdi bu malzemeleri kullanarak adada neyin nerede olduğunu belirleyelim denir ve mekân oluşturulur. Gruba kraftlar, duvara asmaları için yapıştırıcılar, yere belirleme yapacaklarsa renkli elektrik bantları, renkli kalemler, sahili belirlemek için isterlerse kullanabilecekleri deniz kabukları verilir.

4. Etkinlik: Mekân oluşturulduktan sonra katılımcılar çembere çağrılır 4'er kişilik gruplar oluşturulur. Birinci, beşinci ve onuncu gün, yaşadığınız problemi görebileceğimiz 3 donuk imge tasarlamak için grup çalışması yapacaklarını ve bunun için 5 dakika hazırlık zamanları olduğu belirtilir. Gruplar arka arkaya izlenir.

Her güne ait donuk imgeler tekrar izlenir ve "Problem ne?, Problem neyden ya da kimden kaynaklanıyor?" gibi sorularla problemin saptanması sağlanır ve problem durumları tahtaya yazılır.

Donuk imgeler üzerinden, "Buradaki problemlerin çözülmesi gerekli mi? Muhtemel çözümler neler olabilir?” gibi sorularla çözüm yolu önerileri alınır. Bu problemlerin çözümü için kendilerinin ortak kararları doğrultusunda ada kurallarının oluşturulacağı belirtilir. Ada kuralları yazılı bir kâğıt duvara asılır ve şu an yazmak istedikleri kuralları oy birliği ile yazabilecekleri söylenir. Süreç içinde ihtiyaç duyulduğu zaman değişilebilir ve eklenebilir olduğu belirtilir.

\section{Ara}

5. Etkinlik: Grup çemberde iken adada belli bir süreliğine kalınıyor olsa da bir takım işlerin yapılması gerektiği ve bunun için muhtemel işlerin ne olabileceği hakkında konuşulur. Bu sırada herkese kâğıt kalem dağıtılır. Bu esnada katılımcılardan gelen iş adları tahtaya yazılır ve görev tanımları yapılır. Katılımcılara ellerinde bulunan kâğıtlara her bir iş adını uzaktan okunabilecek biçimde yazmaları ve mekânda herhangi bir yere bırakmaları istenir. "Mekânda, kâğıtların arasında müzik eşliğinde yürümeleri istenir. Müzik durduğunda en çok istedikleri işin başına geçmek için üç adım hakları olduğu söylenir. Lider, "Yakındakiler küçük adımlarla, uzaktakiler büyük adımlarla isteklerine en yakın işe ilerleyebilir. Bir kâğıdın başında birden fazla kişi olabilir. Mümkün olduğunca mekânın her yerini dolaşmalısınız” der. Lider, hiç kimsenin gitmediği kâğıtları yerden kaldırır. Ve her seferinde kâğıtların mesafeleri daha da açılır. En az kâğıt kalana kadar etkinlik devam eder.

Etkinlik değerlendirmesi: Elenen kâğıtlardaki işler tahtaya yazılır? Buna göre bu görevler arasında oyundan çıkan görevlerin adadan da çıkarılıp çıkarılamayacağı hakkında tartışılır.

6. Etkinlik: Bir önceki atölyede, gemideki görevlerine göre yaptıkları önem sıralamasını tekrar oluşturmaları istenir. Bu sıra içinde sayışma yoluyla 4 grup oluşturulur. Aşağıdaki dramatik durumlar dağıtılır ve hazırlık için 5 dakikaları olduğu söylenir. Tüm canlandırmalar izlenir.

\section{Dramatik Durum:}

İşleri aranızda paylaşmanız istendi. Sizler de adada yapılacak işler listesine göre iş bölümü yapmaya çalışıyorsunuz. Buna göre sizden yaka kartınızdaki görev tanımlarınızı da göz önünde bulundurarak bir paylaşım yapmanız isteniyor.

Aranızdan kimileri daha düşük konumda gördüğü görevleri üstlenmek istemiyor. Sonunda isteyerek ya da istemeyerek de olsa bir görevi üstlenmeniz gerek. 


\section{Dramatik Durum:}

İşleri aranızda paylaşmanız istendi. Sizler de adada yapılacak işler listesine göre iş bölümü yapmaya çalışıyorsunuz. Buna göre sizden yaka kartınızdaki görev tanımlarınızı da göz önünde bulundurarak bir paylaşım yapmanız isteniyor.

Aranızdakilerden bazıları adada bir lidere ihtiyaç olduğunu düşünüyor ve bunu en iyi kendisinin yapacağını düşünüyor. Sonunda isteyerek ya da istemeyerek de olsa bir görevi üstlenmeniz gerek.

\section{Dramatik Durum:}

İşleri aranızda paylaşmanız istendi. Sizler de adada yapılacak işler listesine göre iş bölümü yapmaya çalışıyorsunuz. Buna göre sizden yaka kartınızdaki görev tanımlarınızı da göz önünde bulundurarak bir paylaşım yapmanız isteniyor.

İşlerinizin görev tanımları aynı değildir. Bazılarınız bundan dolayı daha ayrıcalıklı olmak istiyor. Sonunda isteyerek ya da istemeyerek de olsa bir görevi üstlenmeniz gerek.

\section{Dramatik Durum:}

İşleri aranızda paylaşmanız istendi. Sizler de adada yapılacak işler listesine göre iş bölümü yapmaya çalışıyorsunuz. Buna göre sizden yaka kartınızdaki görev tanımlarınızı da göz önünde bulundurarak bir paylaşım yapmanız isteniyor.

Adada bazıları bazı iş kollarının diğerlerinden daha çok çalıştığını ama diğerlerinin daha az çalıştığını düşünüyor. Sonunda isteyerek ya da istemeyerek de olsa bir görevi üstlenmeniz gerek.

\section{Değerlendirme:}

7. Etkinlik: Bütün katılımcılara daha önceden hazırlanan "Ada Değerlendirme Formu" (Ek 3) dağıtılır. Katılımcılar bu formu atölye sürecinde oluşturulan gemi yaşantısından yola çıkarak cevaplandırırlar.

8. Etkinlik:Katılımcılar çember biçimini oluşturur ve yere otururlar. Lider katılımcılara, tüm atölye sürecin düşünerek paylaşmak istedikleri herhangi bir şey olup olmadığını sorar. Bu soruya cevap vermek isteyenlerin yanıtları dinlenir. Daha sonra lider katılımcıların hepsinden bu atölyede en çok ön plana çıkan veya en önemli olan şeyin ne olduğu sorar. Bu soruya bütün katılımcılardan en az bir cümlelik yanıt alınır.

\section{EK 2: Ada Değerlendirme Formu}

\begin{tabular}{|l|l|}
\hline Gemideki statüm: & \\
\hline Adadaki statüm: & \\
\hline Adada iş bölümü yapılmasına gerek vardı/yoktu. Çünkü \\
\hline Gemideki rolüm, adadaki rolümü etkiledi/etkilemedi. Çünkü... \\
\hline Adadaki iş bölümündeki hiyerarşi bana şunları hissettirdi \\
\hline İş bölümünde hiyerarşik sıralama olmalı/olmamalı çünkü... \\
\hline
\end{tabular}

